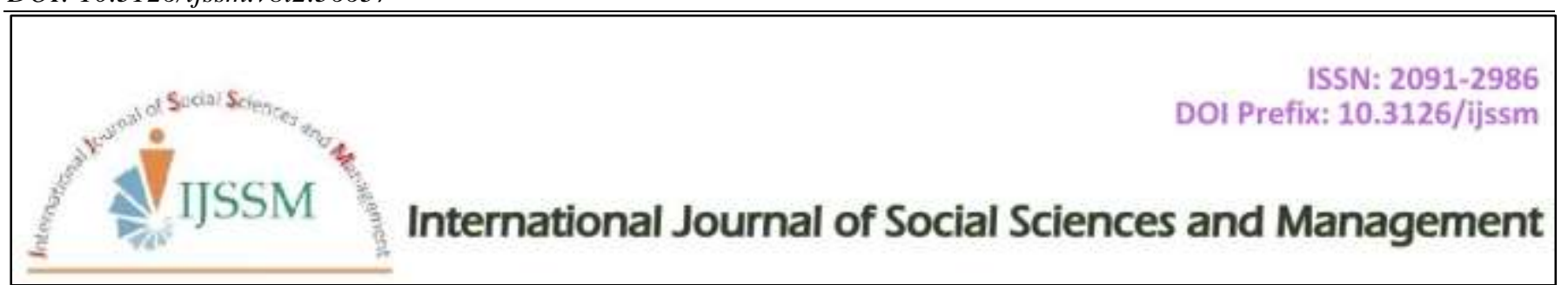

Mini Review

\title{
Impact of COVID-19 On Nepalese Economy
}

\author{
Santosh Kumar Karn
}

Faculty of Management, R.R.T.J. Multiple Campus, Golbazar, T.U., Nepal

Article Information
Received: 15 March 2021
Revised version received: 24 April 2021
Accepted: 26 April 2021
Published: 28 April 2021
Cite this article as:
S.K. Karn (2021) Int. J. Soc. Sc. Manage. 8(2): 348 -
351. DOI: $10.3126 / i j s s m . v 8 i 2.36637$
*Corresponding author
Santosh Kumar Karn,
Faculty of Management, R.R.T.J. Multiple Campus,
Golbazar, T.U., Nepal
Email: Santoshkarn803@ gmail.com
Peer reviewed under authority of IJSSM
(C) 2021 IJSSM, Permits unrestricted use under the
CC-By-NC license.
OPEN ACCESS
This is an open access article \& it is licensed under a
Creative Commons Attribution Non-Commercial 4.0
International
(https://creativecommons.org/licenses/by-nc/4.0/)
Keywords: Covid-19; Lockew; Impact Econgy

Keywords: Covid-19; Lockdown; Impact; Economy of Nepal

\section{Introduction}

COVID-19 the first case was identified in Wuhan, China in December 2019. The disease has since spread worldwide, leading to an ongoing pandemic. The World has been gripped by a pandemic over the first half of 2020. It was identified as a new coronavirus (severe acute respiratory syndrome coronavirus 2, or SARS-CoV-2), and later named as Coronavirus Disease-19 or COVID-19 (Qiu et al., 2020). While COVID-19 originated in the city of Wuhan, it has spread rapidly across the world, resulting in a human tragedy and tremendous economic damage. The

\begin{abstract}
The worldwide pandemic of COVID-19 has caused human losses and severely affected the global economy and passing in a turmoil situation. The COVID 19 pandemic is having a significant economic as well as health impact in Nepal. The economy of Nepal is also grappled by the severe public health crisis of the Covid19. As the public health emergency is heavily interconnected with economic affairs, it has impacted each of the pillars of the economy. This article focuses on COVID19 impact on economic growth in Nepal. The main purpose of this paper is to make evaluations of the potential impact of the COVID-19 pandemic on the economy of Nepal has resulted in historically the highest agriculture, remittance unemployment and biggest fall in GDP.
\end{abstract}


consequences like unemployment and poverty (Rodela et al., 2020). Undeniably, the COVID-19 pandemic is taking an unprecedented toll on global economy along with public health and livelihood issues. Magnitude of the economic losses will depend on how the outbreak evolves as any pandemic diseases and its economic consequences are vastly ambiguous which makes it challenging for policymakers to work out an axiomatic and appropriate macroeconomic policy (Alam et al., 2020). The COVID-19 pandemic is resulting in a major global recession (World Bank, 2020b).

The first COVID-19 case was confirmed in Nepal on 23 January 2020 when a 31-year-old student, who had returned to Kathmandu from Wuhan on 9 January, tested positive for the disease (Wikipedia). It has spread rapidly across the world, resulting in a human tragedy and tremendous economic damage. Nepal's economy is projected to grow by only 0.6 percent in 2021, inching up from an estimated 0.2 percent in 2020 as lockdowns caused by COVID-19 disrupt economic activity, due to increasing unemployment resulting from the nationwide lockdown (World Bank, 2020). The COVID 19 pandemic has shaken the entire world. It has infected over 106.797721million people in more than 223 countries, areas or territories, the death toll reached 2.341145 million. Nepal it has infected over 2 lakhs 72 thousand 4 hundred 30 and death toll reached 2 thousand 52, by 11 February 2021 and continues to rise (WHO, 2021).

\section{Objectives}

The main purpose of this study is to potential impact of the COVID-19 pandemic on the economy of Nepal. The study uses the monthly data of various economic indicators, notably agriculture, remittances, local trade, international trade, government revenues, employment obtained from Nepal Rastra Bank (NBR). The data compared to the months of the same period of the previous year. The study collected most of the review material from different published data of NRB. All the figures shown in the data are in million Nepali Rupees (NPR).

\section{Impact of COVID-19 on the Economy of Nepal}

The COVID-19 has already affected whole countries and regions in the world. Economically developed countries are failed to tackle this pandemic situation. In comparing developed countries, the developing and poor countries are unable to meet this condition. Nepal is a least developed country and used isolation and lockdown to stopped the spread of this deadly virus. Due to lockdown and isolation, the economy of Nepal is seriously affected. Nepal imposed a lockdown to control the spread of the coronavirus since 24 March 2020 and partially opened since the first week of September 2020. The lockdown has affected the overall physical, mental, social and spiritual health of the people and posed unique challenges with vulnerable populations and limited resources to respond to the pandemic (Poudel and Subedi, 2020). The economic impact of COVID-19 covers as under various sectors described below.

\section{Agriculture}

Agriculture sector is a major sector of the economy in terms of income, employment and food security in Nepal. The contribution of agricultural sector (agriculture, forest and fisheries) in total Gross Domestic Product is estimated to be 27.7 percent in the current fiscal year 2019/20 (Economic Survey 2019/20, MOF). The agricultural crops, livestock and fisheries are not outside the impact of COVID-19. Being an agricultural country, the travel restriction and lockdown have affected every stage of the food supply chain, including food production and distribution in Nepal. Farmers are compelled to dump milk and vegetables after a significant decrease in supply and closure of processing companies and proper markets (Poudel et al., 2020).

The implementation of lockdown has affected all sectors in the country including agriculture. The ability of farmers fully stopped to sell their products in the markets which affected income and food loosed. The disruption on the agricultural inputs supply has caused shortages of seeds, fertilizers, veterinary medicines, and feed for animals. Furthermore, delays in the harvest of wheat and lentils have been reported as well as delays on land preparation for vegetable production (key high-income crops), rice and maize. Delayed planting of spring maize and rice (major crops) can have a long-term effect on the overall agricultural production and livelihoods of farmers. The loss of jobs and incomes as a result of the lockdown has pushed the vulnerable population into further food and nutritional insecurity.

\section{Foreign Remittance}

Remittance is the lifeblood of many developing countries in the world like Nepal. The country is embraced with a huge population, but this population is assets for the country because they are well known as a remittance fighter and worked in different parts of the world. As per Nepal Rastra Bank's report. The Status of Remittance Inflow in Nepal', Nepal received a total of NPR 879.3 billion (USD7.8 billion) in remittance in the fiscal year (FY) 2018/19, which is a contribution of $25.4 \%$ to the national GDP of NPR 3.4 trillion (USD 29.8 billion). Remittances have become a major contributing factor to increasing household income as well as country's GDP. About 30 percent of Nepal's GDP comes in the form of remittance money which is sent home by Nepalese working abroad and it helps to reduce country's poverty rate. Due to COVID-19 pandemic outbreak from January 2020 onwards has seemingly changed many parameters in the world economy, society, politics, and culture. The remittance sending behavior, trends, volumes are changed. Remittance income will be severely affected 
due to COVID-19 pandemic. The income fell by $0.2 \% \mathrm{y} / \mathrm{y}$ in mid-February 2020 after rising by $16.0 \%$ in the year earlier period. Remittance income, about $8 \$$ billion per fiscal year, or $26 \%$ of GDP, is one of the major sources of foreign earnings. A sharp decline of remittance will undermine Nepal's external stability (ADB, 2020).

In Nepal lockdown was started from 24 March, 2020 to 21 July, 2020 due COVID-19 crisis migrant workers returning to Nepal from foreign countries. An estimated 800,000 migrant workers are returning home from places such as the Middle East and India (Mercy Crops). People backed to Nepal as a result of the flow of remittance tremendously decreasing in the last few months. The foreign remittance will come down and thus it will hit the foreign reserves of the country. The amount of foreign remittance mid-month of March 2020 was Rs.79.2 billion and each month the flow of remittance significantly decreased because, a large number of people unemployed in abroad, and most of them were backed in the home. The mid-month of Sep to December gradually increasing.

The flow of remittance slightly improving from mid-month September increase by $8.1 \%$, Sep-Oct $12.6 \%$, Oct-Nov $11.2 \%$ and Nov-Dec $10.9 \%$, it shows a positive sign because, worldwide locked down opened (Table 1).

\section{Flow of Export and Import}

Foreign Trade (Export and Import) Nepal is in Southern Asia, bordering between north in China and East, west and south in India. The country has experienced rapid economic growth in recent years mainly driven by exports of cardamom, jute goods, polyster yarn and threads, noodles and pashmina. The country is largely depended on imported products from neighboring countries. After the outbreak of Covid-19, the import and export-oriented companies are also at risk. Business people fear the country's imports and exports will further decrease in the coming days because of the worsened coronavirus situation. The data compared to the months of the same period of the previous year. The Table 2 shows the export- import position of the last month in Nepal.

Mid-August exports increased 8.9 percent to Rs.9.62 billion. Mid-September exports increased 10.5 percent to Rs. 20.44 billion. mid-Oct exports increased 14.3 percent to Rs.31.05 billion mid-Nov exports increased 10.8 percent to Rs.40.20 billion mid-Dec exports increased 5.1 percent to Rs.50.06 billion (Table 2).

Table 3 shows that mid-Aug- imports decreased 19.6 percent to Rs.85.81 billion, mid-Sep imports decreased 22.1 percent to Rs.178.85 billion, mid-Oct imports decreased 12.7 percent to Rs.292.27 billion, mid-Nov imports decreased 10.6 percent to Rs.402.49 billion and Mid-Dec imports decreased 9.6 percent to Rs.525.50 billion. Data compared to the months of the same period of the previous year.

Table-1: Flow of Remittance (Amount NPR in Billion)

\section{Mid-Month/2020}

\begin{tabular}{|l|l|l|l|l|l|l|l|l|l|l|}
\hline Month & Feb-Mar & Mar-Apr & Apr-May & May-Jun & Jun-July & July-Aug & Aug-Sep & Sep-Oct & Oct-Nov & Nov-Dec \\
\hline Amount & 79.2 & 34.5 & 53.9 & 94.0 & 101.4 & 92.7 & 165.7 & 258.8 & 337.7 & 416.8 \\
\hline
\end{tabular}

Source: Various reports on the current Macroeconomic and Financial situation and tables published by Nepal Rastra Bank (NRB).

Table-2: Flow of Export (Amount NPR in Billion)

\begin{tabular}{|l|l|l|l|l|l|l|l|l|l|l|}
\hline \multicolumn{10}{|c|}{ Mid-Month/2020 } \\
\hline Month & Feb-Mar & Mar-Apr & Apr-May & May-Jun & Jun-July & July-Aug & Aug-Sep & Sep-Oct & Oct-Nov & Nov-Dec \\
\hline Amount & 9.9 & 3.9 & 3.3 & 5.9 & 9.7 & 9.6 & 20.4 & 31.0 & 40.2 & 50.0 \\
\hline
\end{tabular}

Source: Various reports on the current Macroeconomic and Financial situation and tables published by NRB.

Table 3: Flow of Import (Amount NPR in Billion)

\begin{tabular}{|l|l|l|l|l|l|l|l|l|l|l|}
\hline \multicolumn{10}{|c|}{ Mid-Month/2020 } \\
\hline Month & Feb-Mar & Mar-Apr & Apr-May & May-Jun & Jun-July & July-Aug & Aug-Sep & Sep-Oct & Oct-Nov & Nov-Dec \\
\hline Amount & 120.6 & 58.3 & 42.6 & 75.7 & 96.0 & 85.8 & 178.8 & 292.2 & 402.4 & 525.5 \\
\hline
\end{tabular}

Source: Various reports on the current Macroeconomic and Financial situation and tables published by NRB. 
Table 4: Flow of Revenue (Amount NPR in Billion)

\begin{tabular}{|l|l|l|l|l|l|l|l|l|l|l|}
\hline \multicolumn{10}{|c|}{ Mid-Month/2020 } \\
\hline Month & Feb-Mar & Mar-Apr & Apr-May & May-Jun & Jun-July & July-Aug & Aug-Sep & Sep-Oct & Oct-Nov & Nov-Dec \\
\hline Amount & 54.4 & 43.9 & 16.1 & 41.1 & 146.0 & 58.8 & 105.3 & 172.3 & 240.1 & 301.2 \\
\hline
\end{tabular}

Source: Various reports on the current Macroeconomic and Financial situation and tables published by NRB.

\section{Government Revenue}

Government revenue is money received by a government from taxes and non-tax sources to enable it to undertake government expenditures. The trends of revenue mobilization for the period from Mid-Month Feb-March 2020 to Mid-Month Nov-December is shown in Table 4.

Mid-August revenue collection based on banking transactions (including the amount to be transferred to provincial and local governments) stood at Rs.58.81 billion, mid-Sep Rs.105.37 billion, mid-Oct Rs.172.36 billion, mid-Nov Rs.240.15 billion and mid- December Rs.301.23 billion.

\section{Conclusions and Suggestions}

This study shows that the outbreak of Covid-19 is paralyzed whole sector of the world as well as economy. Nepal is also face an economic slowdown and fall in a great difficulty because this country largely depends on foreign remittance and exports of cardamom, jute goods, polyester yarn and threads, noodles, pashmina, palm oil, pulses, zinc sheet, handicrafts, and skin. Due to COVID-19 crisis migrant workers returning to Nepal from foreign countries. The exportation declined. A huge number of the population is unemployed and increasing depression among this unemployed. The amount of foreign remittance from midmonth of March 2020 to mid-month of August was the flow of remittance significantly decreased because, a large number of people unemployed in abroad, and most of them were backed in the home due to worldwide lockdown. But mid-month of September to mid-month of December gradually increasing. As well as shows the position export also indicate from mid-month of September to increasing and import decreases compared to the months of the same period of the previous year and government revenue is increasing gradually from mid-month of September. The result shows the Nepalese economy was fully affected by COVID-19. The flow of situation slightly improving which show a positive sign because, worldwide locked down opened. Now, vaccine available gradually.

The challenging for policymakers to fulfill the gap of Nepalese economy today, the study suggested that Covid19 still surfacing all over the world so, some steps are suggested to provide the vaccine for all population in the country, availability of seeds and fertilizers adequately to the farmers at the time, to make easy loan process to the needy entrepreneur and ensure the reliable foreign employment by the government agencies of Nepal to mitigate possible threats for the economy.

\section{References}

Alam MS, Ali MJ, Bhuiyan AB, Solaiman M, Rahman MA. (2020) The Impact of COVID-19 Pandemic on The Economic Growth in Bangladesh: A Conceptual Review. American Economic \& Social Review 6(2): 1-2.

Economic Survey 2019/20, Government of Nepal Ministry of Finance Singh Durbar, Kathmandu. Retrieved from: https://mof.gov.np/uploads/document/file/Economic\%20 Survey\%202019_20201125024153.pdf

Government of Nepal Ministry of Finance (2019/20), Economic Survey Retrieved from: https://mof.gov.np/uploads/document/file/Economic\%20 Survey\%202019_20201125024153.pdf.

Poudel K and Subedi P (2020) Impact of COVID-19 pandemic on socioeconomic and mental health aspects in Nepal. Int $J$ Soc Psychiatry 66(8):748-55.

Poudel PB, Poudel MR, Gautam A, Phuyal S, Tiwari CK \& Bashyal S (2020) COVID-19 and its global impact on food and agriculture. Journal of Biology and Today's World 9(5): 221-225.

Qiu Y, Chen X \& Shi W (2020) Impacts of Social and Economic Factors on the Transmission of Coronavirus Disease 2019 (COVID-19) in China (Working Paper 494). GLO Discussion Paper. https://www.econstor.eu/handle/10419/215739.

Rodela TT, Tasnim S, Mazumder H \& Faizah F (2020) Economic Impacts of Coronavirus Disease (COVID-19) in Developing Countries. https://osf.io/preprints/socarxiv/wygpk/

World Bank (2020) Press Release: COVID-19 impact on Nepal's economy hits hardest informal sector.

World Bank 2020b. Press Release: COVID-19 to Plunge Global Economy into Worst Recession since World War II. Washington D.C.

Asian Development Bank, Nepal Macroeconomic Update, April 2020 Volume 8, No. 1.

WHO (2021) COVID-19 update - Thursday 11th February 2021. Retrieved from https://health.gov.tt/covid-19-updatethursday-11th-february-2021 